\title{
THE STATE OF FAMILY FARMERS IN THREE COUNTRIES OF CENTRAL
} AMERICA

\author{
Hala Shahin ${ }^{1}$, Gil Pessanha Penha-Lopes ${ }^{1}$ \\ ${ }^{1}$ Faculty of Sciences, University of Lisbon, Centre for Ecology, Evolution and Environmental Changes, Portugal \\ E-mail: halajshahin@gmail.com, gppenha-lopes@fc.ul.pt
}

\begin{abstract}
This study aims to describe the state of family farmers in Panama, Costa Rica and El Salvador, and to examine the differences between the perspective of the family farmers and the policymakers in this regards. To achieve this aim, 90 in-depth, structured, close-ended interviews were conducted with ninety study participants throughout the fieldwork, 30 participants in each country divided equally into policymakers and family farmers. The obtained results confirm that family farmers are facing challenges that limit their production capacity due to unequal access to production resources, unjust distribution of power, and lack of supportive policies. Developing the right policies to strengthen family farmers, improve the efficiency of the rural organization, and guarantee rural generation sustainability, will help to enhance the performance of family farmers in producing sustainable, culturally approved food and improve food and nutrition security.
\end{abstract}

Keywords: Food sovereignty, family farmers, rural institutional framework, agricultural policies

\section{O ESTADO DA AGRICULTURA FAMILIAR EM TRÊS PAÍSES DA AMÉRICA CENTRAL}

\section{RESUMO}

Este estudo tem como objetivo descrever o estado das famílias dos agricultores no Panamá, Costa Rica e El Salvador, e examinar as diferenças de perspectiva entre os agricultores e decisores políticos a este respeito. Para atingir esse objetivo, foram realizadas 90 entrevistas aprofundadas, estruturadas e fechadas com 90 participantes do estudo ao longo do trabalho de campo, 30 participantes em cada país, divididos igualmente entre formuladores de políticas e agricultores familiares. Os resultados obtidos confirmam que os agricultores familiares enfrentam 
desafios que limitam sua capacidade de produção devido ao acesso desigual aos recursos de produção, distribuição injusta de poder e falta de políticas de apoio. O desenvolvimento de políticas adequadas para fortalecer os agricultores familiares, melhorar a eficiência da organização rural e garantir a sustentabilidade da geração rural ajudará a melhorar o desempenho dos agricultores familiares na produção de alimentos sustentáveis e culturalmente aprovados e na melhoria da segurança alimentar e nutricional.

Palavras-chave: Soberania alimentar, agricultores familiares, marco rural institucional, políticas agrícolas

\section{INTRODUCTION}

\section{Family farmers and food security}

Developing countries are facing many global challenges in terms of feeding their populations. The focus on industrial agriculture, monocarps, and genetically modified crops has proven its failure in the efforts to eradicate hunger. Furthermore, industrial agriculture is related to significant destruction in natural resources, biodiversity loss, and climate change (ALTIERI, 2009). The majority of poor and hungry people in the world (70\%) live in rural, remote areas, and they depend on agriculture, fisheries, and forestry as their primary income (CLAEYS, 2019; FAO, 2017). In many developing countries, agriculture was based on family farms that use local natural resources as well as local and indigenous farming knowledge. These family farms employ almost $75 \%$ of the active rural population, and they produce a significant share of the family food (ALTIERI, 2009; FAO, 2017). It is estimated that there are 570 million farms around the world; 500 million of these farms are family farms. These farms are distributed differently around the world, 74\% in Asia, 9\% in Sub-Saharan Africa, 7\% in Europe, 4\% in Latin America and 3\% in the Middle East and North Africa. About $84 \%$ of the farms in the world are smaller than 2 hectares, and they operate about $12 \%$ of the farmland (LOWDER et al., 2016). Many studies consider family farmers highly relevant for achieving food security; this is because family farmers contribute to a significant share of food production around the world (LOWDER et al., 2016). Family farms have higher productivity than large monoculture farm in terms of total production; this could be due to the efficient use of natural resources in these farms (ALTIERI \& NICHOLLS, 2008; GRAEUB et al., 2016). Moreover, family farmers have the potential to double food production in the world, especially in some of the most vulnerable areas, and surpass 
the yields of large-scale farmers. Furthermore, these farms can increase the nutrition values of food on the community and household level, by providing varieties of crops at the same time and ensuring adequate diet (FAO, 2013; GRAEUB et al., 2016). Family farmers contribute up to 53\% of food production in the world. In Latin America, family farmers produce up to $41 \%$ of food consumed domestically and up to $51 \%$ of the maize, $77 \%$ of the beans and $61 \%$ of the potatoes that are consumed around the world (ALTIERI \& TOLEDO 2011; GRAEUB et al., 2016). Almost $81 \%$ of farms in Latin America are family farms; they produce between $27 \%$ and $67 \%$ of the local food; and contribute to $57 \%$ to $77 \%$ of rural employment in the region. Smallholder farmers occupy almost 35\% of the cultivated land in Latin America (CELAC, 2018; IFAD 2013).

This article describes the situation of family farmers from the perspective of policymakers, and family farmers; their access to the production resources, financial support, education as well as the presence of a political focus for this group of farmers, and the current laws and policies that prioritize them. Besides, a comparison between the perspective of farmers and the perspective of decision-makers is provided.

\section{Family farmers, poverty and biodiversity}

The majority of poor and hungry people in the world live in rural, remote areas, and they depend on agriculture, fisheries, and forestry as their primary source of income (FAO, 2017). Moreover, most of the world poor live in rural areas (70\%), and 52\% of rural people still live in poverty in Latin America (CHAPPELL et al., 2013; CLAEYS, 2019). In Latin America, poverty rates have increased in the period 2014-2018 from 27.8 to 29.6, and extreme poverty rates has also increased from 7.8 to 10.2 (ECLAC, 2019). Furthermore, the number of people suffering from undernourishment, poverty and extreme poverty is expected to increase in 2020 , due to the spread of the COVID-19 pandemic that affected the income, thus the access to food for an estimated of 186-216 million people who are projected to suffer from poverty and 67.5-83.4 million to suffer from extreme poverty (FAO \& CELAC 2020). Moreover, it is projected that the region will be facing one of the worst economical and social crises with a drop of 5.3 in the Gross Domestic Product (GDP) (FAO, 2020). Furthermore, as the rates of unemployment and under employment has increased in response to the pandemic, the purchase power will decrease, and the demand will decrease which in turn will affect the producers, and will cause a rise in food prices (FSIN, 2020). In this regards the effect of the pandemic on the rural production will 226 
depend on the availability of agriculture labour, the accessibility to production inputs, the season production and the accessibility to infrastructure, transport and to the local market (FSIN, 2020).

Rural areas in Latin America have the highest inequality in rural areas around the world with a Global Information Networking Institute (Gini) coefficient higher than 0.5 for the majority of countries and limited access to land, with land ownership GINI coefficient of 0.78 for the region (ECLAC, 2017b). Moreover, the sparse rural population is trapped in a cycle of poverty, because of the increasing population in rural areas, natural resources will be more frequently exploited, this will decrease productivity, and therefore people who are dependent on this production will remain poor (GRAEUB et al., 2016).

Even though agriculture is recognized as a significant cause of biodiversity loss, not all types of agriculture affect biodiversity the same way. Monoculture agriculture with intensive use of agrochemical may cause soil degradation, habitat destruction, species and can affect the value of non-commodity services like simplifying landscapes (PINTO-CORREIA \& KRISTENSEN, 2013; GRAEUB et al., 2016). On the other hand, diversified agroecological agriculture with low external input (which is practiced in small farms) supports biodiversity conservation, by minimizing the use of chemicals, protecting the wildlife and using soil conservation practices through increasing the diversity and rotation of crops (GRAEUB et al., 2016). Furthermore, the diversity of crops in family farms helps to maintain the genetic pool of plants and animals, and helps to improve resilience to climate change since local species are usually more adapted and resilient compared to the modern varieties (IFAD, 2013). In Mexico and Guatemala, family farmers continue using a traditional polyculture system called Malpa, which is a combination of corn, beans, squash, chilies, and other edible plants. This system not only provides food and economic stability, but it also preserves cultural value, resources and helps to conserve many wild varieties that are associated with this traditional system (CHAPPEL et al., 2013).

\section{Family farmers in Central America}

Family farmers in Central America have some typical characteristics; a self-managed economic unit, the predominant use of family labour, limited access to land and capital, dependence, and heterogeneity (LEPORATI et al., 2014).

There are around 7.4 million farms (agriculture establishments) in Central America and Mexico, $78.6 \%$ of these establishments (5.8 million) can be considered family farms. The largest 
number of family farms is in Mexico $(4,104,505)$ followed by Guatemala $(830,684)$, El Salvador $(397,433)$ Honduras $(317,199)$, Nicaragua $(268,527)$ Panama $(248,560)$ and the smallest number is in Costa Rica $(79,000)$ (SCHNEIDER, 2016). The average size of family farms in the region is 3.13 hectares (SCHNEIDER, 2016). This average varies among the different countries in the region from 1 hectare in Guatemala to 6.8 hectares in Nicaragua (ECLAC et al., 2013). The majority of family farmers in the region are self-employed farmers (61\%) that consider agriculture as their primary income. Most of the family farmers in Central America rely mainly on family labour, while $35 \%$ of family farmers are subsistence farmers that consider agriculture as their second activity. Finally, in Central America, like the whole region of Latin America, high rates of poverty are associated with family farmers, $63 \%$ of family farmers in Central America are still living in poverty (SCHNEIDER, 2016).

\section{Background of the countries of the study}

For this study, three Central American countries were chosen, Panama, Costa Rica, and El Salvador. The fact that these countries have a different economic and social background, yet they share many common problems in the aspects of food security, agricultural production, and family farmers, is the reason for choosing these examples. Panama has been one of the fastest-growing economies in Latin America over the past decade, with real Gross Domestic Product (GDP) expanding an average that reached 8.3\% in 2017, yet decreased to 5.9\% in 2018 (CEPAL, 2019). Moreover, Panama performed relatively well during the global financial crisis, including a 4.0\% growth in 2009 when many other countries in the region suffered a contraction (ECLAC, 2017a). On the other hand, Costa Rica, despite being a small and open economy, has maintained a positive GDP growth rate since 1990, which reached $3.4 \%$ in 2017 , yet decreased to $2.7 \%$ in 2018 (CEPAL, 2019). El Salvador is a small country highly populated; in fact, it is the most populated country in Central America (WFP, 2017). In recent years, El Salvador had the slowest economic growth in Central America. It has an average of $1.9 \%$ of growth during the period between 2010 and 2016. This growth reached 2.4 in 2016, due to improvements in the trade balance, including a decline in both imports and exports, with a more significant decrease in imports. In 2018, the economy registered a real growth of 2.5\% (CEPAL, 2019). The overall unemployment rate reached 7\%, while youth unemployment rates reached $14.2 \%$ in 2016. 
Inequality measured by the Global Information Networking Institute (GINI) coefficient has declined by about 4\% between 2006 and 2015 to reach 0.48 in 2015 (WFP, 2017).

All of the three countries have achieved progress in the fight against hunger, yet they are still facing different challenges. One of the most critical challenges in the area of nutrition is that of obesity as a new type of malnourishment. In Costa Rica, $8.1 \%$ of children under the age of five are overweight (FAO, 2015). Moreover, in El Salvador, overweight and obesity affect $60 \%$ of adults and 6\% of children under the age of five (WFP, 2016).While overweight, and obesity in children under the age of five has decreased during the previous years in the Panama and El Salvador, the prevalence of overweight rates has increased in Costa Rica (ECLAC, 2019).

\section{MATERIAL AND METHODS}

Data was collected via two methods. The first method consisted of standardized, closeended interviews with selected participants. The second method was data collection, including documents found through the research via the internet and visits to libraries, as well as documents suggested by the participants and documents collected while attending conferences and meetings. These methods are described in detail in the following paragraphs:

\section{Interviews}

Interviews, as a method of research, have many advantages and values. The value of interviewing is in its holistic view for the topic of research and, more importantly, in its ability to allow the participants to express their thoughts and opinions (BERG, 2009). Furthermore, it is suitable for examining social changes, and complex processes which makes it more fitting to the study objectives (QU \& DUMAY, 2011; ALSHENQEETI, 2014). Nevertheless, this method also has many disadvantages, it is a time-consuming method; it takes a long time since the preparation till the concluding all of the interviews, but at the same time the researcher guarantees higher rates of replies and fewer unanswered questions. Also, there is a room for bias even if subconsciously, the researcher can influence the answers of the respondents even without knowing (ALSHENQEETI, 2014). Moreover, other factors like race, sex, age, and social class can affect the respondent answers and honesty (GILLHAM, 2007). Furthermore, sometimes the respondent will try to impress the interviewer by giving unrealistic answers that he thinks the interviewer wants to hear (HARRIS \& BROWN, 2010). The Structured interviews or 
standardized interviews are type of interviews with the main characteristic that it is based on a predetermined, identical set of questions, and are usually referred to as quantitative research interviews because it can easily collect quantifiable data. It is similar in form to a questionnaire, with the difference that the questions in the interviews are read out loud by the researcher, the questionnaire on the other hand is read by the respondent (QU \& DUMAY, 2011; ALSHENQEETI, 2014). Structured interviews are less flexible which can limit the information provided by the respondents, on the other hand, it is less time consuming, and has the capacity to replicate which makes testing the validity easier (ADAMS \& COX, 2008).

The main method used for collecting data in this study was the structured face to face interviews. In total, 90, structured, close-ended interviews conducted with 90 study participants throughout the fieldwork, 30 respondents in each of Panama, Costa Rica, and El Salvador. The respondents were distributed in three categories: food experts, employees in an international organization, and employees in a governmental institution. The sample size was a fixed number of 30 interviews for each country in each chapter; this was highest feasible number that the time and resources' limitations allowed. There are many factors that play a role in deciding the sample size of interviews; the aim and the design of the study, the type of data collected and the nature of the studies issue. Still a sample size of 30 is considered an acceptable size (MASON, 2010). The same sample size was applied in each country, so the data obtained can be more comparable and the results more reliable. Moreover, this can be useful for future comparison between the results obtained in the three chapters. The participants were chosen using purposive non-probability sampling. In the purposive or judgmental sampling technique the respondents are chosen freely by the interviewers according to specific criteria, commonly according to their knowledge and experience with the subject investigated in the study. Non-probability sampling is the most suitable sampling technique when conducting an interview, it is entirely non-random, and it has many advantages in comparison to the probabilistic sampling, these advantages include being less costly and much faster than other sampling techniques (SAUNDERS et al., 2009). The respondents who met the study criteria (years of experience working in institutions or agencies with issues like food security, food sovereignty, rural developments, local farmers, food policies, professors and publishing authors concerned about the study issues, long time farmers, farmers organizations workers), were contacted via telephone or email, after completing the interview each respondent was asked to refer another respondent who meets the criteria following the 230 
snowball sampling strategy. Snowball sampling is applied when the respondents are hard to access, it is a gradual multi-step process (NADERIFAR et al., 2017). The protocol was provided in both English and Spanish. The following table shows the questions and the optional responses provided in the interview protocol (Table 1).

Table 1. The questions and their optional answers provided in the interview protocol in Panama, Costa Rica and El Salvador, 2020.

\begin{tabular}{ll}
\hline Question and question number & Options of answers \\
\hline Q1. Which of the following categories most represents your & An employee in an international organization. \\
current occupation? & (Policymakers) \\
& An employee in a governmental institution. \\
& (Policymakers) \\
& Family farmers' representative. (Family farmers). \\
\hline Q2. Please select your gender & A peasant. (Family farmers). \\
\hline Q3. Please select the age group that represents you & Male \\
& Female \\
\hline
\end{tabular}

Q4. How do you describe the family farmer's access to land?

Full access

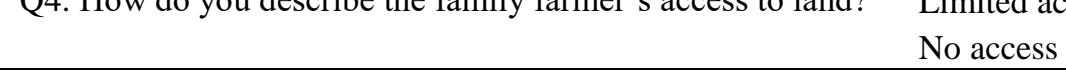

Full access

Q5. How do you describe the family farmer's access to water, electricity and other resources?

Limited access

No access

Q6. How do you describe the family farmer's access to local Full access market?

Limited access

No access

Strong

Q7. How do you describe the institutional framework for the development of family farming?

Weak

It does not exist

Yes. Please give examples

Q8. Are there rural development policies that support family farmers?

No

Q9. Do family farmers receive any form of education concerning sustainable production practices?

Yes. Please give examples

No

Q10. Do family farmers receive any form of financial support to improve their production?

Yes. Please give examples

No

Q11. Are there favourable discrimination policies to support women farmers?

Yes. Please give examples

No 
Table 1. The questions and their optional answers provided in the interview protocol in Panama, Costa Rica and El Salvador, 2020 (continued).

\section{Question and question number}

Q12. Are there public policies that encourage youth to stay in rural areas?

\section{Options of answers}

Yes. Please give examples

No
Q13. Are family farmers represented in a rural organization?

Q14. In your opinion, what are the most critical barriers that small family farmers are facing in the country?
Yes. Please give examples

No

Lack of supporting policies.

Lack of implementation of the existing policies.

Lack of financial support.

Lack of access to resources.

Lack of access to the market.

All of the options above.

Other reason. Please specify

Q15. In your opinion, what are the factors that can encourage the most, the development of small family farmers in the situation of the country?
Increase awareness of the importance of family farmers.

Develop information systems for Family Farmers.

Include family farmers in the policy design process.

Create an institutional frame-work for family farmers.

Create programs for rural youth.

Create programs to support rural women's development.

Improve access to productions resources.

Increase access to local markets.

Increase financial support.

All of the options above can be applied to support family farmers. 


\section{Interviews process}

The respondents recruiting process started with respondents who fits the criteria (described before), that I found through my research or through previous connections with FAO sub regional office for Mesoamerica, SICA (Sistema de la Integración Centroamericana) Central America Integration System), SISCA (Secretaría de la Integración Social Centroamericana), the Rural Regional Dialogue Program (Programa de Diálogo Regional Rural) (PDRR), and The National Committee of Family Agriculture (el Comité Nacional de Agricultura Familiar).This was followed by interviewing the individuals that fits the criteria mentioned previously, that were recommended by the respondents. The participants were invited to participate via phone or email, or sometimes personally when we met in an event. Interviews took place mainly at the place of work of the individual, and in some case in a café following the request of the respondent. The questions were provided in both English and Spanish. In total, 143 invitations were sent, 10 were rejected (7\%), 44 were unanswered (30\%), and 90 agreed and completed the interview/questionnaire $(63 \%)$.

\section{Data analysis}

For this study, the statistical analysis used the SPSS statistical package and software R, version 3.60. The first step was coding the collected data (the answers to the questions). Each question was treated as a variable, and each option for each question was given a number. Then, descriptive statistics for each question/variable to check the frequencies of the results among all the data were applied. Finally, Pearson chi-squared taste was applied to assess the different frequencies of responses given by each country, $\mathrm{p}>0.05$ indicates that there is no enough information to reject the null hypothesis, and there are no differences between the answers provided by the interviewees of the three countries as they all have similar opinions. For the other scenario, $\mathrm{p}<0.05$ tells that there is statistical evidence to reject the null hypothesis and to say that from the three countries, at least one has a different view on that question, and that can be seen by looking at the data and identifying the differences.

\section{RESULTS AND DISCUSSION}

The results of the interviews were summarized in Table 2 and Table 3. Table 1 shows the proportions of the respondents in each country by each category of the questionnaire and the 
significant difference between countries. Table 2 shows the percentages of Family Farmers (FF) and Policy Makers (PM) by each category of the questionnaire and the significant difference between occupations.

Table 2. The proportion of the respondents in each country by each category of the questionnaire, and p-values for the Pearson's Chi-squared. P-values below 0.05 assume a significant contrast of opinions between at least one of the three countries. The analyses indicate that there is a significant difference between the answers of the respondents of the three countries in four questions. Question \#5 How do you describe the FF access to resources? ( $\mathrm{p}=0.006)$; question \#6 How do you describe the FF access to the local market? ( $<<0.001)$; question \#13 Are family farmers represented in rural organizations? ( $\mathrm{p}<0.001)$; and question \#15 What are the main encouragements on the development of small FF? $(\mathrm{p}=0.008)$. Values followed by an asterisk $(*)$ indicate the test statistics was performed only considering options whose mean was different from zero - answers that at least one individual had selected, and values underlined means that there is a significant difference between the answers of the respondents in Panama, Costa Rica and El Salvador, 2020.

\begin{tabular}{|c|c|c|c|c|c|c|c|}
\hline $\begin{array}{c}\text { Question } \\
\#\end{array}$ & Definition & Categories & Panama & $\begin{array}{l}\text { Costa } \\
\text { Rica }\end{array}$ & $\begin{array}{c}\text { El } \\
\text { Salvador }\end{array}$ & Mean & $\begin{array}{c}\text { P- } \\
\text { value }\end{array}$ \\
\hline \multirow[t]{2}{*}{$\# 1$} & \multirow[t]{2}{*}{ Occupation } & Family farmers & 50.00 & 50.00 & 50.00 & 50.0 & $\sim 1.000$ \\
\hline & & Policymakers & 50.00 & 50.00 & 50.00 & 50.0 & \\
\hline \multirow[t]{2}{*}{$\# 2$} & \multirow[t]{2}{*}{ Gender } & Male & 63.33 & 66.67 & 56.67 & 62.2 & 0.718 \\
\hline & & Female & 36.67 & 33.33 & 43.33 & 37.7 & \\
\hline \multirow[t]{3}{*}{$\# 3$} & \multirow[t]{3}{*}{ Age group } & $20-40$ & 0.00 & 3.33 & 0.00 & 1.11 & \\
\hline & & $40-60$ & 63.33 & 53.33 & 50.00 & 55.5 & 0.535 \\
\hline & & $60-80$ & 36.67 & 43.33 & 50.00 & 43.3 & \\
\hline \multirow[t]{3}{*}{$\# 4$} & \multirow[t]{3}{*}{ Land } & Full access & 0.00 & 0.00 & 0.00 & 0.00 & \\
\hline & & Limited access & 100.00 & 100.00 & 100.00 & 100.00 & $\sim 1.000$ \\
\hline & & No access & 0.00 & 0.00 & 0.00 & 0.00 & \\
\hline \multirow[t]{3}{*}{$\# 5$} & \multirow{3}{*}{$\begin{array}{l}\text { Water, electricity, and } \\
\text { other resources }\end{array}$} & Full access & 0.00 & 6.67 & 0.00 & 2.22 & \\
\hline & & Limited access & 100.0 & 93.33 & 83.33 & 92.22 & 0.006 \\
\hline & & No access & 0.00 & 0.00 & 16.67 & 5.56 & \\
\hline \multirow[t]{3}{*}{$\# 6$} & Market & Full access & 0.00 & 0.00 & 0.00 & 0.00 & \\
\hline & & Limited access & 86.67 & 100.00 & 50.00 & 78.89 & $<0.00 *$ \\
\hline & & No access & 13.33 & 0.00 & 50.00 & 21.11 & \\
\hline \multirow[t]{2}{*}{$\# 7$} & Institutions & Strong & 0.00 & 0.00 & 0.00 & 0.00 & $\sim 1.000$ \\
\hline & & Weak & 100.0 & 100.00 & 100.00 & 100.00 & \\
\hline \multirow[t]{2}{*}{$\# 8$} & Development & Yes & 80.00 & 63.33 & 60.00 & 67.78 & 0.207 \\
\hline & & No & 20.00 & 36.67 & 40.00 & 32.22 & \\
\hline
\end{tabular}


Table 2. The proportion of the respondents in each country by each category of the questionnaire, and p-values for the Pearson's Chi-squared. P-values below 0.05 assume a significant contrast of opinions between at least one of the three countries. The analyses indicate that there is a significant difference between the answers of the respondents of the three countries in four questions. Question \#5 How do you describe the FF access to resources? ( $p=0.006)$; question \#6 How do you describe the FF access to the local market? ( $p<0.001)$; question \#13 Are family farmers represented in rural organizations? ( $\mathrm{p}<0.001)$; and question \#15 What are the main encouragements on the development of small FF? $(\mathrm{p}=0.008)$. Values followed by an asterisk $(*)$ indicate the test statistics was performed only considering options whose mean was different from zero - answers that at least one individual had selected, and values underlined means that there is a significant difference between the answers of the respondents in Panama, Costa Rica and El Salvador, 2020 (continued).

\begin{tabular}{|c|c|c|c|c|c|c|c|}
\hline $\begin{array}{c}\text { Question } \\
\#\end{array}$ & Definition & Categories & Panama & $\begin{array}{l}\text { Costa } \\
\text { Rica }\end{array}$ & $\begin{array}{c}\text { El } \\
\text { Salvador }\end{array}$ & Mean & $\begin{array}{c}\text { P- } \\
\text { value }\end{array}$ \\
\hline \multirow[t]{2}{*}{$\# 9$} & \multirow[t]{2}{*}{ Education } & Yes & 100.0 & 100.00 & 93.33 & 97.78 & \multirow[t]{2}{*}{0.129} \\
\hline & & No & 0.00 & 0.00 & 6.67 & 2.22 & \\
\hline \multirow[t]{2}{*}{$\# 10$} & \multirow[t]{2}{*}{ Finances } & Yes & 66.67 & 70.00 & 60.00 & 65.56 & \multirow[t]{2}{*}{0.709} \\
\hline & & No & 33.33 & 30.00 & 40.00 & 34.44 & \\
\hline \multirow[t]{2}{*}{$\# 11$} & \multirow[t]{2}{*}{ Women } & Yes & 0.00 & 0.00 & 0.00 & 0.00 & \multirow[t]{2}{*}{$\sim 1.000$} \\
\hline & & No & 100.0 & 100.00 & 100.00 & 100.00 & \\
\hline \multirow[t]{2}{*}{$\# 12$} & \multirow[t]{2}{*}{ Youth } & Yes & 0.00 & 0.00 & 0.00 & 0.00 & \multirow[t]{2}{*}{$\sim 1.000$} \\
\hline & & No & 100.0 & 100.00 & 100.00 & 100.00 & \\
\hline \multirow[t]{2}{*}{$\# 13$} & \multirow[t]{2}{*}{ Organizations } & Yes & 100.0 & 76.67 & 50.00 & 75.56 & \multirow[t]{2}{*}{$<0.001$} \\
\hline & & No & 0.00 & 23.33 & 50.00 & 24.44 & \\
\hline \multirow[t]{8}{*}{$\# 14$} & \multirow[t]{8}{*}{ Barriers } & Lack of policies & & & & & \multirow{8}{*}{$0.062 *$} \\
\hline & & $\begin{array}{c}\text { Lack of } \\
\text { implementation }\end{array}$ & 0.00 & 6.67 & 0.00 & 2.22 & \\
\hline & & \multirow{2}{*}{$\begin{array}{l}\text { Lack of financial } \\
\text { support }\end{array}$} & 3.33 & 13.33 & 13.33 & 10.00 & \\
\hline & & & 26.67 & 20.00 & 33.33 & 26.67 & \\
\hline & & \multirow{2}{*}{$\begin{array}{l}\text { Lack of resources } \\
\text { access }\end{array}$} & 10.00 & 6.67 & 0.00 & 5.56 & \\
\hline & & & 23.33 & 13.33 & 0.00 & 12.22 & \\
\hline & & $\begin{array}{l}\text { Lack of market } \\
\text { access }\end{array}$ & 36.67 & 40.00 & 53.33 & 43.33 & \\
\hline & & All of the above & & & & & \\
\hline
\end{tabular}


Table 3. The proportion of Family Farmers (FF) and Policy Makers (PM) by each category of the questionnaire, and p-values for the Pearson's Chi-squared to test the difference between the responses of the two occupations. P-values below 0.05 assume a significant contrast of opinions between FF and PM. There are some statistically significant categories, where Family farmers and Policymakers differed from one another. Question \#5 How do you describe the FF access to resources? ( $p=0.029$ ); question \#6 How do you describe the FF access to the local market? $(p=0.039)$; question \#8 Are there rural development policies that support family farmers? $(\mathrm{p}<0.001)$; question \#13 Are family farmers represented in rural organizations? $(\mathrm{p}<0.00)$, and question $\# 14$, what are the most critical barriers? $(\mathrm{p}=0.001)$. Values followed by an asterisk $(*)$ indicate the test statistics was performed only considering options whose mean was different from zero - answers that at least one individual had selected, and values underlined means that there is a significant difference between the answers of policymakers and family farmers for this question in Panama, Costa Rica and El Salvador, 2020.

\begin{tabular}{|c|c|c|c|c|c|c|}
\hline $\begin{array}{c}\text { Questions } \\
\#\end{array}$ & Definition & Categories & $\begin{array}{l}\text { Family } \\
\text { farmers }\end{array}$ & $\begin{array}{c}\text { Policy } \\
\text { makers }\end{array}$ & Mean & $\begin{array}{c}\text { P- } \\
\text { value }\end{array}$ \\
\hline \multirow[t]{2}{*}{ \#2 } & Gender & Male & 60.00 & 64.44 & 62.22 & 0.828 \\
\hline & & Female & 40.00 & 35.56 & 37.78 & \\
\hline \multirow[t]{3}{*}{$\# 3$} & Age group & $20-40$ & 2.22 & 0.00 & 1.11 & \\
\hline & & $40-60$ & 55.56 & 55.56 & 55.56 & 0.599 \\
\hline & & $60-80$ & 42.22 & 44.44 & 43.33 & \\
\hline \multirow[t]{3}{*}{ \#4 } & Land & Full access & 0.00 & 0.00 & 0.00 & $\sim 1.000$ \\
\hline & & Limited access & 100.00 & 100.00 & 100.00 & \\
\hline & & No access & 0.00 & 0.00 & 0.00 & \\
\hline \multirow[t]{3}{*}{$\# 5$} & Water, & Full access & 0.00 & 4.44 & 2.22 & \\
\hline & electricity & Limited access & 88.89 & 95.56 & 92.22 & 0.029 \\
\hline & & No access & 11.11 & 0.00 & 5.55 & \\
\hline \multirow[t]{3}{*}{$\# 6$} & Market & Full access & 0.00 & 0.00 & 0.00 & \\
\hline & & Limited access & 68.89 & 88.89 & 78.89 & $0.039 *$ \\
\hline & & No access & 31.11 & 11.11 & 21.11 & \\
\hline \multirow[t]{2}{*}{$\# 7$} & Institutions & Strong & 0.00 & 0.00 & 0.00 & $\sim 1.000$ \\
\hline & & Weak & 100.00 & 100.00 & 100.00 & \\
\hline \multirow[t]{2}{*}{$\# 8$} & Development & Yes & 48.89 & 86.67 & 67.78 & $<0.001$ \\
\hline & & No & 51.11 & 13.33 & 32.22 & \\
\hline \multirow[t]{2}{*}{ \#9 } & Education & Yes & 95.56 & 100.00 & 97.78 & 0.457 \\
\hline & & No & 4.44 & 0.00 & 2.22 & \\
\hline \multirow[t]{2}{*}{$\# 10$} & Finances & Yes & 55.56 & 75.56 & 65.56 & 0.076 \\
\hline & & No & 44.44 & 24.44 & 34.44 & \\
\hline \multirow[t]{2}{*}{$\# 12$} & Youth & Yes & 0.00 & 0.00 & 0.00 & $\sim 1.000$ \\
\hline & & No & 100.00 & 100.00 & 100.00 & \\
\hline \multirow[t]{2}{*}{$\# 13$} & Organizations & Yes & 62.22 & 88.89 & 75.56 & 0.007 \\
\hline & & No & 37.78 & 11.11 & 24.45 & \\
\hline
\end{tabular}


Table 3. The proportion of Family Farmers (FF) and Policy Makers (PM) by each category of the questionnaire, and p-values for the Pearson's Chi-squared to test the difference between the responses of the two occupations. P-values below 0.05 assume a significant contrast of opinions between FF and PM. There are some statistically significant categories, where Family farmers and Policymakers differed from one another. Question \#5 How do you describe the FF access to resources? ( $\mathrm{p}=0.029)$; question \#6 How do you describe the FF access to the local market? $(\mathrm{p}=0.039)$; question \#8 Are there rural development policies that support family farmers? $(\mathrm{p}<0.001)$; question \#13 Are family farmers represented in rural organizations? $(\mathrm{p}<0.00)$, and question \#14, what are the most critical barriers? $(\mathrm{p}=0.001)$. Values followed by an asterisk $(*)$ indicate the test statistics was performed only considering options whose mean was different from zero - answers that at least one individual had selected, and values underlined means that there is a significant difference between the answers of policymakers and family farmers for this question in Panama, Costa Rica and El Salvador, 2020 (continued).

\begin{tabular}{|c|c|c|c|c|c|c|}
\hline $\begin{array}{c}\text { Questions } \\
\#\end{array}$ & Definition & Categories & $\begin{array}{l}\text { Family } \\
\text { farmers }\end{array}$ & $\begin{array}{c}\text { Policy } \\
\text { makers }\end{array}$ & Mean & $\begin{array}{c}\text { P- } \\
\text { value }\end{array}$ \\
\hline \multirow{7}{*}{$\# 14$} & Barriers & Lack of policies & 4.44 & 0.00 & 2.22 & \multirow{7}{*}{$0.001 *$} \\
\hline & & Lack of implementation & 20.00 & 0.00 & 10.00 & \\
\hline & & Lack of financial support & 22.22 & 31.11 & 26.66 & \\
\hline & & Lack of resources access & 11.11 & 0.00 & 5.55 & \\
\hline & & Lack of market access & 11.11 & 13.33 & 12.22 & \\
\hline & & All of the above & 31.11 & 55.56 & 43.34 & \\
\hline & & Other & 0.00 & 0.00 & 0.00 & \\
\hline \multirow[t]{11}{*}{$\# 15$} & Encouragements & Increase awareness & 0.00 & 0.00 & 0.00 & \multirow{11}{*}{$0.407 *$} \\
\hline & & Develop information systems & 0.00 & 0.00 & 0.00 & \\
\hline & & Inclusion in policy & 0.00 & 0.00 & 0.00 & \\
\hline & & Institutional framework & 0.00 & 0.00 & 0.00 & \\
\hline & & Programs for youth & 0.00 & 0.00 & 0.00 & \\
\hline & & Programs to support women & 0.00 & 0.00 & 0.00 & \\
\hline & & Access to resources & 6.67 & 4.44 & 5.55 & \\
\hline & & Access to markets & 6.67 & 4.44 & 5.55 & \\
\hline & & Financial support & 13.33 & 4.44 & 8.88 & \\
\hline & & All of the above & 73.33 & 86.67 & 80.00 & \\
\hline & & Other & 0.00 & 0.00 & 0.00 & \\
\hline
\end{tabular}

In regards to the access to the production resources, the entire respondents in both groups (family farmers and policymakers) in Panama, Costa Rica, and El Salvador agreed that there is a limited access to land. The majority of the respondents agreed that there is a limited access to water, electricity, and market, except for El Salvador, as the majority decided that there is no access to the market at all. In regards to the access to water and market, El Salvador is significantly different from the other two countries. There is a significant difference also between family farmers and policymakers regarding the same two questions. Despite the changes in the socio-economic conditions and the political conditions, still, rural farmers have not yet benefited from these changes. Many challenges still face family farmers, including the limited access to 
natural resources and proper financial support (SCHNEIDER, 2016; FAO \& IFAD 2019). In accordance, FAO's Regional Initiative to reduce rural poverty and enhance food security and nutrition through rural territorial development focuses mainly on improving access to production resources (FAO, 2014a). Moreover, FAO regional initiative considers El Salvador as one of the eight priority countries for the rural development, and it focuses mainly on improving access to natural resources, as only $39.6 \%$ of the family farmers in El Salvador own the land they work in (FAO, 2014a; SCHNEIDER, 2016). Furthermore, in many countries of Latin America, family farmers suffer from big inequality in access to production resources, especially to land and water, which limits their production capacity (AMEKAWA et al., 2010; NEHRING, 2012). Moreover, access to market can be restricted by many factors including the distance to the market and the availability of ways to transfer, the economic limitations of the framers, as well as having the market controlled and monopolized by big producers (NEHRING, 2012). In this regards the effect of the pandemic on the rural production will depend on the availability of agriculture labour, the accessibility to production inputs, the season production and the accessibility to infrastructure, transport and to the local market (FSIN, 2020). Moreover, many countries in Latin America have adopted measures to facilitate the access to production resources, and the market. As well as providing financial support, or delay in the payments of credits (FAO \& CELAC, 2020). Panama for example has implemented a green line that farmers can use to transport the production input to the farms, and their production to different markets, especially that in many countries in the region the rainy season begins between April and May, and this is usually the time that farmers start planting their seasonal production (FAO \& CELAC, 2020). In addition, most of the countries in the region have formed policies to support the vulnerable population, especially farmers to guarantee a consistent agriculture production, yet the weak economy is limiting the implementation of these policies (FAO, 2020).

All of the respondents agreed that there is a weak institutional framework for the development of family farmers. Focusing on the development of the institutional structure, the effectiveness and the strength of civil society is the way to face the complicated challenges that are present in this region (PIÑEIRO, 2005). In regards to the existence of rural development policies, the majority of family farmers in Panama said these policies exist; the percentage of family farmers who agreed on this was less than half in both Costa Rica and El Salvador. All policymakers in Panama said yes, it exists as well as the majority in Costa Rica and El Salvador. 
In 2011, the ministry of agriculture in Costa Rica (MAG) published the Sectoral Plan for Rural Development 2011-2014. This plan is considered as the short-term implementation of the State Policy for the Agrifood Sector and the Costa Rican Rural Development 2010-2021 (MAG, 2011b). The general objective of this plan was to improve the income from agricultural activities, through the competitiveness, technological innovation, the balanced development of the rural areas, and the sustainable agro-environmental management of the Sector (MAG, 2011b). The State Policy for the Agrifood Sector and Costa Rican Rural Development 2010-2021 has been defined on four pillars divided into strategic areas and sub-areas: competitiveness, technological innovation, rural territories, and family agriculture, Climate Change and Agro-environmental Management. Each pillar has a specific objective (MAG, 2011b). In El Salvador, there has been a particular policy for family farming since 2011. In 2011, the ministry of agriculture (MAG) in El Salvador had implemented the Family Farming and Rural Entrepreneurship Plan for Food and Nutrition Security (PAF). This plan targets the families living in poverty in rural areas of the country (MAG, 2011a). The plan consists of 4 programs: national supply program for food and nutritional security, family farming program for productive chains, agricultural innovation program, and liaison program with industry and trade (MAG, 2011a). The family farming program for productive chains (PAP) aims to increase the level of income net of rural families through the improvement of the competitiveness of rural businesses and productive chains. It also aims to increase agriculture production and the production of commercial family farmers, increase the participation of producers in formal, informal, local, regional, and national markets, and ensure financial support for the farmers (MAG, 2011a).

Nevertheless, the results that we have achieved show a significant difference between the responses of the family farmers and the policymakers to this question. These results could be due to the lack of the implementation of strategic plans and policies, which makes it less reflective in the real situation and daily life of the family farmers. In 2015, a study to analyze "The Central American Strategy for Rural Territorial Development as a regional policy regarding the rural territorial development of the Central American Integration System" found that even if the design of the policies have positive qualities, the problem is related to the implementation of the policies, the lack of funds and the weak involvement of the national governments (FERNÁNDEZ \& SANTOS, 2015). Moreover, in 2011, the ministry of agriculture (MAG) in El Salvador has implemented the Family Farming and Rural Entrepreneurship Plan for Food and Nutrition 
Security (PAF). However, no better results in regards to the state of family farmers or the state of food sovereignty were dedicated in the case of El Salvador in this study. There is a real struggle for the implementation of food sovereignty and rural development policies, mainly because many policies don't cover the aspects of accessing the production resources and the market, nor the changes in the trade systems, and the support that the state will provide (GODEK, 2013).

Furthermore, to design successful rural development policies, these policies should include all the involved actors in rural production and development, to guarantee equal participation and privileges for all the public agencies, civil society organization, and the state as well as equal representations for both men and women farmers. Besides, there is a need to guarantee the right of all the rural actors and to ensure that the rules are correctly enforced and finally facilitate the connection between all the actors by having a well-connected network of all the actors (DAVIS, 2003; FAO \& IFAD 2019). Moreover, in order for these policies to be implemented in the most effective way, it should include some strategies about controlling and accessing the resources to be more suitable for the real life situation and local sovereignty (MCKAY \& NEHRING, 2013).

All the family farmers in Panama said they receive education about sustainable agriculture practices, as well as the majority of respondents in both Costa Rica and El Salvador. All the policymakers in the three countries also said yes, there is some form of education in this regard. In this context, planning forums and workshops can be very beneficial in educating both farmers and governmental employees, about food sovereignty, agroecology and other sustainable agriculture practices (GODEK, 2013). The family farmers in the three countries were divided in opinion about the financial support that they receive; still, Costa Rica showed the highest rate of family farmers receiving financial aid. On the other hand, the majority of the policymakers said that family farmers receive some form of financial support. In most of the cases, the banks have very restricted and rigid requirements to give loans and credits to family farmers, which makes it more challenging to access these loans (ECLAC et al., 2019). This could explain the difference between the responses of the farmers and the responses of policymakers, even if the financial support does exist in the form of private credits, farmers may not have access to it and therefore not consider it as a support in real life. Governments can overcome this problem by encouraging the banks to have reasonable requirements more relatable to the actual situation of rural and family farmers, and offering subsidies for the agriculture loans which in turn will encourage the 
commercial banks to give these types of loans (ECLAC et al., 2015). Furthermore, many governments in the region have postponed the payment of agriculture related loans. Panama, for example approved a bill, to delay the payments of the loans for one year, and in Costa Rica the Rural Development Institute (Inder), has also declared a postpone for paying the capital and the interest of loans related to the Rural Credit programme (FAO \& CELAC, 2020).

In the example of Brazil family farmers are the main providers of the locally consumed food in the country; around 70\% of the food that is consumed in Brazil is produced by family farmers that rely mainly on family labour, using only $25 \%$ of the agricultural land. Still, they receive much less governmental support in comparison with the industrial export focused farmers (WITTMAN \& BLESH, 2015). In 1995, the National Program for Strengthening Family Agriculture (PRONAF) was created to provide credits and loans for family farmers, and increase their access to market. This was followed by the creation of The Ministry of Agrarian Development (Ministério de Desenvolvimento Agrário, MDA) in 1999, that is specialized in supporting family farmers, and which supervises the work of PRONF (GUANZIROLI \& BASCO, 2010). In this context, two programs on the national level have the most relevant effect on family farmers. The first is the Food Acquisition Program (Programa de Aquisicão de Alimentos) (PAA), that was created in 2003, with the main aim of distributing healthy quality food purchased exclusively from family farmers to socially vulnerable people and people suffering from food insecurity (GUANZIROLI \& BASCO, 2010; OLIVEIRA et al., 2017). The second is the National School Feeding Program (Programa Nacional de Alimentação Escolar) (PNAE), wich was first created in 1953 to improve the students' diet and nutrition, the aim of PNAE was reformulated in 1979 to cover at least $15 \%$ of the daily need of students while they are in school, and then in 2009 in include improving health, education, diet of students, as well as rural development, and improving the social situation of the local family farmers by emphasizing that at least $30 \%$ of the food served in the school feedings should be bought from family farmers. This program has a high coverage of 45 million students in the country in all public schools, and is considered one of the most important food and nutrition strategies in Brazil, as it combines both food security and rural development (SIDANER et al., 2012; OLIVEIRA et al., 2017). The two programs encourage agroecological practices, organic production system, and the diversifications of production. They also improve the local income and the life of the farmers, and they create future marketing opportunities through building a network and connecting 
producers with managers, local dealers and the program staff (OLIVEIRA et al., 2017). Nevertheless, family farmers that participate in these programs have some difficulties and face some challenges including the lack of the coordination between the supply that the farmers are capable of providing due to seasonal changes and economic and infrastructure limitations, and the restrict demand of the stable school menus' demand all year long that doesn't consider the real capacity of the local farmers. As well as the high cost that farmer need to cover to transport their food, through remote badly structured roads that often compromise the quality of the produce (SIDANER et al., 2012; WITTMAN \& BLESH, 2015). Finally, to be accepted in these programs farmers needs to be a member of an association, which is unfavourable for some farmers as it implies more extended political aspect, than just food marketing (WITTMAN \& BLESH, 2015). In a similar attempt in Venezuela, the Venezuelan Agricultural Corporation initiative (CVA) guarantees a fair market for the farmers to sell their product in a stable fair price. It plays a very important part in connecting producers and consumers directly and protecting them from being exploited by intermediaries. On the other hands, this empowers farmers to be in control of their production, how to produce it and how to sell it (MCKAY \& NEHRING, 2013).

The entire respondents in both groups agreed that there are no policies that support neither rural women nor rural youth. FAO emphasize on the importance of including rural women in public policies, especially that the majority of them have very little to no access to all the production resources or the financial support knowing that women are responsible for at around $50 \%$ of the labour force (SCHNEIDER, 2016; FAO \& IFAD, 2019). In addition, women and girls represent $60 \%$ of the population affected by malnutrition and chronic hunger (CLAEYS, 2019). Moreover, women have higher rates of poverty in comparison to men in Latin America (ECLAC, 2019). On the other hand, to achieve food security and production sustainability, it is essential to privilege rural youth and encourage them to stay living in rural areas and continue agriculture production (FAO, 2014b). Furthermore, the action plan of the UN Decade for Family Farmers 2019-2028 has included the support of rural youth and rural women in the main pillars of the action plan. By "ensuring the generational sustainability of family farmers" (pillar 2), and "promoting gender equality and the leadership of women" (pillar 3), many SDGs can be achieved not only SDG2 (end the hunger), but also SDG1 (ending the poverty), SDG4 (ensuring equitable quality education), and SDG8 (economic growth) (FAO \& IFAD, 2019). 
All the family farmers in Panama said that there are rural organizations representing family farmers; the majority in Costa Rica had the same opinion. The policymakers in both Panama, and Costa Rica, and the majority of respondents in El Salvador also said yes. However, the farmers' participation in this organization is still low in the whole region of Latin America (FAO, 2014b). Moreover, rural organization and social movement can defend rural farmers and peasant against agribusiness in the struggle for immaterial territories and especially the land, using the argument that conventional agriculture causes a lot of damage and destruction to the land, the environment and to the human health by using high chemical input and GMO seeds in their production (GODEK, 2013). Many rural social movements have raised during the last two decades in LA, these social movements covered sectors that were usually neglected like indigenous and rural women. All these social movement played a big role in adopting the concept of food sovereignty at the national level. One of the examples is the case of Ecuador, one of the first nations to adopt the concept of food sovereignty, the indigenous social movement organization with other peasant organizations, and NGOs, as part of the whole food sovereignty network were successful in pushing the change of the constitution in 2008, and to have a new constitution following the concept of "Sumak Kawsay" a Kichua indigenous tradition that can be translated to "good living" or "Buen Viver". The new constitution includes the concept of food sovereignty (articles 13, 281, 282), and for Ecuador to be GMO free (401) (PEÑA, 2013).

Most of the respondents in both groups in all of the countries replied that all of these factors (the Lack of supporting policies, the lack of implementation of the existing policies, the lack of financial support, the lack of access to resources and the lack of access to market) challenges the development of family farmers. There is a significant difference between the answers provided to this question between family farmers and policymakers. The results of this question correspond with the results that we have found with the previous questions. Many challenges face the rural development in Central America, such as the economic and trade limitation that is weakening the farmers' ability to compete with the international market. Besides, there is a limited access to production resources more importantly to land and water, which in turn leads to a limitation in the overall production and makes it harder to follow environmentally sustainable production methods. Furthermore, the migration of the majority of rural youth into urban areas seeking for better opportunities is one of the essential challenges especially with the lack of the sufficient financial support and the failure of governments to 
include family farmers in their public policies (IFAD, 2013; FAO, 2014b). As observed in other experiences, these challenges can be defeated through the efforts of social movements like for example the case of Ecuador (MARTINEZ et al., 2018).

All of the respondents in El Salvador in both groups agreed that all of the following factors are essential to support family farmers (Increase the awareness of the importance of family farmers, develop information systems for family farmers, include family farmers in the policy design process, create an institutional frame-work for family farmers, create programs for rural youth, create programs to support rural women development, improve access to productions resources, increase access to local markets and increase the financial support). The majority in Costa Rica and Panama also had the same answer. Moreover, El Salvador was significantly different from the other two countries. The answers to this question are consistent with the previous question, to support the family farmers, we need to resolve the challenges that they face. There are many factors to support the development of family farmers, beginning with establishing a better understanding of family farmers in the region, their heterogeneity, and complex as well as their characteristics, and including farmers in the decision-making process and the rural organization and encouraging the youth to stay in their areas by providing better financial support (SCHNEIDER, 2016).

In Central America, none of the countries in the region has a basic territorial strategy related to family farmers; most of the countries have sectoral plans related to the sector of agriculture, including in some case family farming. In the case of El Salvador and Costa Rica, they have sectoral plans related to family farmers framed in sectoral policies related to agriculture. In the case of Panama, Guatemala, and Honduras, they consider family farmers as part of the agricultural sectoral policies. While in Nicaragua, it is included in the rural development plans (ECLAC et al., 2019). In March 2010, the Central American Strategy for Rural Territorial Development (Estrategia Centroamericana de Desarrollo Rural Territorial ECADERT) was approved by the Council of Ministers of the Central American Agricultural Council (CAC). Later on June 19, 2010, the Summit of Heads of State and Governments of the Central American Integration System (Sistema de la Integración Centroamericana - SICA) ratified this policy (CAC, 2010). Furthermore, the ECADERT process also privileges family farming and focal territories, cross-border (discontinuous and located in several countries). This Central American integration instrument adopts the category of "small business agriculture" (the 
type of family farming strongly market-oriented that prioritized the Central American agricultural policy) but assigns particular importance to another type of family agriculture called "peasant family agriculture," which is characterized by combining production for the market and selfconsumption. It also points out the existence of other forms of family agriculture, such as those with a collective basis in ancestral lands and various associative forms (SABOURIN et al., 2014). Besides, the Community of Latin American and Caribbean States (CELAC) have approved the Regional Strategy for Disaster Risk Management (DRM) during the IV Ministerial Meeting on Family Farming and Rural Development that was held in San Salvador, El Salvador in December 2017. This strategy has the main focus on family farmers as the most vulnerable and affected by disasters (CELAC, 2018).

Furthermore, despite the fact that Latin America has enough food production and reserve to provide sufficient food for the population in the long term, the short term access to food is the real challenge that the region faces during the pandemic, especially by the most vulnerable populations of small farmers, landless farmers, indigenous community, immigrants, who has limited, or informal income. Some countries in the region like El Salvador and Honduras are facing problems in food availability in some local markets (FAO, 2020).

Finally, there is still much work to be done in this region to support family farmers and give them the opportunities to reach their highest potentials, starting by building a stronger institutional framework, designing more suitable policies for the situation of each country, and providing the conditions for successful implantation of these policies, especially that the increase in poverty rates, unemployment, and undernutrition will affect more, the already poor and vulnerable, like landless farmers and indigenous communities.

\section{CONCLUSIONS}

Family farmers produce the majority of food production in the region, yet most of the poor and hungry live in rural areas. Even though the three countries of the study, Panama, Costa Rica, and El Salvador, have a different political, social, and economic background, still family farmers in all of them face many common challenges. The results of the study were very similar, indicating limited access to production resources, weak institutional framework, lack of policies, bad implementation of the existent policies, and the absence of positively discriminating policies to favour rural women and youth. Nevertheless, there was a significant difference between the 
countries concerning some of the topics discussed in the interviews, such as the access to the water, to market, the existence of rural organizations, the barriers, and the supporting factors for family farmers.

Furthermore, between family farmers responses and policymakers responses, there was a significant difference related to access to water, to market, the presence of rural development policies, the representation of the rural organization, and the most critical barriers facing family farmers. Policymakers had mostly similar opinions with family farmers, still slightly a more favourable opinion in some of the subjects of the interviews.

Finally, the situation of family farmers in the countries of the study is yet to be improved, family farmers have more barriers than support in the current political and institutional context, including the unrealistic perspective of policymakers to some of the challenges that family farmers face, this gap between the two perspective needs to be filled first, in order to design and implement more successful rural development policies.

\section{REFERENCES}

ADAMS, A.; COX, A. L. 2008. Questionnaires, in-depth interviews and focus groups. Research Methods for Human Computer Interaction, Boston, v.3, p.17-34. https://doi.org/10.1111/j.1460-2466.1996.tb01475.x

ALSHENQEETI, H. 2014. Interviewing as a data collection method: a critical review. English Linguistics Research, Ottawa, v.3, n.1, p. 39-45. https://doi.org/10.5430/elr.v3n1p39

ALTIERI, M. A.; NICHOLLS, C. I. 2008. Scaling up agroecological approaches for food sovereignty in Latin America. Development, Cambridge v.51, n.4, p.472-80. https://doi.org/10.1057/dev.2008.68

ALTIERI, M. A. 2009. Agroecology, small farms, and food sovereignty. Monthly Review, New York, v.61, n.3. Available at: <https://monthlyreview.org/2009/07/01/agroecology-smallfarms-and-food-sovereignty/>. Accesed on: Jun. 5, 2016.

ALTIERI, M. A.; TOLEDO,V. M. 2011. The agroecological revolution in Latin America: rescuing nature, ensuring food sovereignty and empowering peasants. Journal of Peasant Studies, London, v.38, n.3, p.587-612. https://doi.org/10.1080/03066150.2011.582947 Y3 12/09/2015 U6 -

AMEKAWA, Y.; SSEGUYA, H.; ONZERE, S.; CARRANZA, I. 2010. Delineating the multifunctional role of agroecological practices: toward sustainable livelihoods for smallholder farmers in developing countries. Journal of Sustainable Agriculture, London, v. 34, n. 2, p. 202-28. https://doi.org/10.1080/10440040903433079

BERG, B. 2009. Qualitative Research Methods for the Social Sciences, Boston: Allyn \& Bacon., $7^{\text {th }}$ ed. 418 p.

CAC - Central American Agriculture Council. 2010. Estrategia centroamericana de desarrollo rural territorial 2010-2030. CAC, San Jose. Available at: 
$<$ http://repiica.iica.int/docs/B4143e/B4143e.pdf>. Accessed on : Nov. 14, 2017.

CELAC - COMMUNITY OF LATIN AMERICA AND THE CARIBBEAN STATES. 2018. Regional strategy for disaster risk management in the agriculture sector and food and nutrition security in Latin America and the Caribbean (2018 - 2030). CELAC, San Salvador. Available at: <http://www.fao.org/3/i8919en/I8919EN.pdf>. Accessed on: Jun. 2, 2019.

CEPAL - COMISIÓN ECONÓMICA PARA AMÉRICA LATINA Y EL CARIBE. 2019. Estudio económico de América Latina y el Caribe. el nuevo contexto financiero mundial: efectos y mecanismos de transmisión en la región. CEPAL, Santiago. Available at: $<$ https://repositorio.cepal.org/bitstream/handle/11362/44674/221/S1900414_es.pdf>.

Accessed on: Dec. 5, 2019.

CHAPPELL, M. J.; WITTMAN, H.; BACON, C.; FERGUSON, B.G; BARRIOS, L.G.; BARRIOS, R. G.; JAFFEE,D.; LIMA,J.; MÉNDEZ, E.; MORALES, H.; SOTO-PINTO, L.; VANDERMEER, J.; PERFECTO, I. 2013. Food sovereignty: an alternative paradigm for poverty reduction and biodiversity conservation in Latin America. F1000 Research, London, v. 1, p. 1-18. https://doi.org/10.12688/f1000research.2-235.v1

CLAEYS, P. 2019. The rise of new rights for peasants . from reliance on ngo intermediaries to direct representation. Transnational Legal Theory, London, v. 9, n. 3-4, p. 386-399. https://doi.org/10.1080/20414005.2018.1563444

DAVIS, B. 2003. Food, agriculture, and rural development: current and emerging issues for economic analysis and policy research, Rome: FAO, $152 \mathrm{p}$.

ECLAC - ECONOMIC COMISSION FOR LATIN AMERICA AND THE CARIBBEAN. 2012. The outlook for agriculture and rural development in the americas: a perspective on Latin America and the Caribbean - 2013. FAO, IICA, ECLAC, Santiago. Available at: $<$ http://www.fao.org/3/a-as167e.pdf $>$. Accessed on Sep. 13, 2016.

ECLAC - ECONOMIC COMISSION FOR LATIN AMERICA AND THE CARIBBEAN. 2017a. Preliminary Overview of the Economies of Latin America and the Caribbean. ECLAC, Santiago. Available at: $<$ https://repositorio.cepal.org/bitstream/handle/11362/42652/109/S1701282_en.pdf $>$. Accessed on: Mar. 10, 2018.

ECLAC - ECONOMIC COMISSION FOR LATIN AMERICA AND THE CARIBBEAN. 2017b. Social panorama of Latin America. ECLAC, Santiago. Available at: $<$ https://repositorio.cepal.org/bitstream/handle/11362/42717/6/S1800001_en.pdf $>$. Accesed on: Mar. 5, 2018

ECLAC - ECONOMIC COMISSION FOR LATIN AMERICA AND THE CARIBBEAN. 2019 The outlook for agriculture and rural development in the americas: a perspective on Latin America and the Caribbean 2019-2020. FAO, IICA, ECLAC, San Jose. Available at: $<$ https://repositorio.iica.int/bitstream/handle/11324/8214/BVE19040295i.pdf;jsessionid=E94 EDA6DB2E738ACED2D462CC9C2EC59?sequence=2>. Accessed on: Jun. 10, 2020.

ECLAC - ECONOMIC COMISSION FOR LATIN AMERICA AND THE CARIBBEAN. 2019. Quadrennial report on regional progress and challenges in relation to the 2030 agenda for sustainable development in Latin America and the Caribbean. ECLAC, Santiago. Available at: <https://repositorio.cepal.org/bitstream/handle/11362/44552/7/S1900432_en.pdf>. Accessed on: Apr. 12, 2020.

FAO - FOOD AND AGRICULTURE ORGANIZATION OF THE UNITED NATIONS. 2013. Report on the regional dialogue on family farming : towards the international year of family farming challenges, opportunities and policy. FAO, Rome. Available at: 
$<$ https://agriculturafamiliar.dgadr.gov.pt/images/docs/Recursos/LAC_RD_Position_Paper_ag ric_Familiar_Jan_2014.pdf>. Accessed on: Feb. 20, 2016.

FAO - FOOD AND AGRICULTURE ORGANIZATION OF THE UNITED NATIONS. 2014a.

Family farming and rural territorial development in Latin America and the Caribbean. FAO,

Rome. Available at: <http://www.fao.org/3/a-at886e.pdf >. Accessed on: Jul. 30, 2016.

FAO - FOOD AND AGRICULTURE ORGANIZATION OF THE UNITED NATIONS. 2014b.

Towards stronger family farms. Voices in the international year of the family farm. FAO,

Rome. Available at: <http://www.fao.org/3/a-i4171e.pdf>. Accessed on: Apr. 6, 2016.

FAO - FOOD AND AGRICULTURE ORGANIZATION OF THE UNITED NATIONS. 2015.

Regional overview of food insecurity-Latin America and the Caribbean. FAO, Rome.

Available at: < http://www.fao.org/3/a-i4636e.pdf>. Accessed on: Oct. 14, 2018.

FAO - FOOD AND AGRICULTURE ORGANIZATION OF THE UNITED NATIONS. 2016.

FAO 's Regional initiatives for Latin America and the Caribbean. FAO, Rome. Available at: $<$ http://www.fao.org/3/a-i5414e.pdf >. Accessed on: Mar. 22, 2018.

FAO - FOOD AND AGRICULTURE ORGANIZATION OF THE UNITED NATIONS. 2017.

The state of food and agriculture-leveraging food systems for inclusive rural transformation.

FAO, Rome. Available at: <http://www.fao.org/3/a-I7658e.pdf>. Accessed on: Sep. 3, 2019.

FAO - FOOD AND AGRICULTURE ORGANIZATION OF THE UNITED NATIONS. 2020.

Coronavirus disease 2019 (COVID-19). Addressing the impacts of COVID-19 in food crises

(April-December 2020). FAO, Available at:

$<$ http://www.fao.org/3/ca8497en/CA8497EN.pdf>. Accessed on: Jun. 10, 2020.

FAO - FOOD AND AGRICULTURE ORGANIZATION OF THE UNITED NATIONS; CELAC - COMMUNITY OF LATIN AMERICA AND THE CARIBBEAN STATES. 2020. Food security under the COVID-19 pandemic. FAO, Santiago. Available at: <http://www.fao.org/3/ca8873en/CA8873EN.pdf >. Accessed on: Jul. 11, 2020.

FAO - FOOD AND AGRICULTURE ORGANIZATION OF THE UNITED NATIONS; IFAD INTERNATIONAL FUND FOR AGRICULTURAL DEVELOPMENT. 2019. United nations decade of family farming (2019-2028). FAO, Rome. Available at: $<$ http://www.fao.org/3/ca4672en/ca4672en.pdfpdf >. Accessed on: Jan. 17, 2020.

FERNÁNDEZ, L. A.; SANTOS, F. 2015. An analysis of the quality of the central american strategy for rural territorial development (ECADERT) as a regional public policy. Cuadernos de Desarrollo Rural, Bogota, v.12, n. 76, p. 83-107. http://dx.doi.org/10.11144/Javeriana.cdr12-76.aqca

FSIN - FOOD SECURITY INFORMATION NETWORK. 2020. Global report on food crises. joint analysis for better decisions. Available at: $<$ http://ebrary.ifpri.org/utils/getfile/collection/p15738coll2/id/134043/filename/134253.pdf>. Accessed on: Jul. 20, 2020.

GILLHAM, B. 2007. Developing a questionnaire, London: Continuum International Publishing Group, 2nd ed. $112 \mathrm{p}$.

GODEK, W. 2013. The complexity of food sovereignty policymaking: the case of Nicaragua's Law 693. Food Sovereignty: A Critical Dialogue. International Conference, New Haven, p. $1-25$.

GOLAFSHANI, N. 2003. Understanding Reliability and Validity in Qualitative Research. The Qualitative Report, Toronto, v.8, n.4, p. 597-606. Available at: <http://nsuworks.nova.edu/tqr/vol8/iss4/6>. Accessed on: Sep. 28, 2017. 
GRAEUB, B. E.; CHAPPELL, M. G.; WITTMAN, H.; LEDERMANN, S.; KERR, R. P.; GEMMILL-HERREN, B. 2016. The state of family farms in the world. World Development, Amesterdam, v.87, p. 1-15. https://doi.org/10.1016/j.worlddev.2015.05.012

GUANZIROLI, C.; BASCO, C. 2010. Construction of Agrarian policies in brazil: the case of the national program to strengthen family farming (PRONAF). Comuniica Magazine, San Jose, p. 44-63. https://doi: 10.22004/ag.econ.188598

HARRIS, L.; BROWN. G. 2010. Mixing interview and questionnaire methods: practical problems in aligning data. Practical Assessment Research \& Evaluation, Boston, v.15, n.1, p1-19. https://doi.org/10.1126/scitranslmed.3001318

IFAD - INTERNATIONAL FUND FOR AGRICULTURAL DEVELOPMENT. 2013. Smallholders, food security and the environment. IFAD, Rome. Available at: <https://www.ifad.org/documents/38714170/39135645/smallholders_report.pdf/133e89030204-4e7d-a780-bca847933f2e>. Accessed on: Jan. 23, 2018.

IIKER, E.; MUSA, S. A.; ALKASSIM, R.S. 2016. Comparison of convenience sampling and purposive sampling. American Journal of Theoretical and Applied Statistics, Nicosia, v.5, n.1, p. 1-4. https://doi.org/10.11648/j.ajtas.20160501.11

LEPORATI, M.; SALCEDO, S.; JARA, B.; BOERO, V.; MUÑOZ. M. 2014. Agricultura familiar en américa latina y el caribe: recomendaciones de política. Available at: $<$ http://www.fao.org/fileadmin/user_upload/AGRO_Noticias/docs/RecomendacionesPolAgri FAMLAC.pdf>. Accessed on: Feb. 13, 2017.

LOWDER, S. K.; SKOET, J.; RANEY. T. 2016. The number, size, and distribution of farms, smallholder farms, and family farms worldwide. World Development, Amesterdam, v.87, pp. 16-29. https://doi.org/10.1016/j.worlddev.2015.10.041

MAG - MINISTERIO DE AGRICULTURA Y GANADERIA DE EL SALVADOR. 2011 a. Plan de agricultura familiar y emprendedurismo rural para la seguridad alimentaria nutricional (paf) 2011-2014. Ministerio De Agricultura y Ganaderia El Salvador. Available at: <http://extwprlegs1.fao.org/docs/pdf/els146625.pdf >. Accessed on: Sep. 20, 2017.

MAG - MINISTERIO DE AGRICULTURA Y GANADERIA DE COSTA RICA. 2011b. Plan sectorial de desarrollo agropecuario 2011-2014. Available at: <http://www.mag.go.cr/bibliotecavirtual/a00303.pdf>. Accessed on: Sep. 30, 2017.

MARTINEZ, A.; RUIVENKAMP, G.; JONGERDEN, J. 2018. Drafting a law , dissolving a proposal: food sovereignty and the state in Ecuador. Agrarian South: Journal of Political Economy, Tousand Oaks, v.7, n.3, pp. 1-30. https://doi.org/10.1177/2277976018800590

MASON, M. 2010. Sample size and saturation in phd studies using qualitative interviews. Fqs forum: qualitative social research, Berlin, v. 11, n.3. https://doi.org/http://dx.doi.org/10.17169/fqs-11.3.1428

MCKAY, B.; NEHRING, R. 2013. The state of food sovereignty in Latin America: political projects and alternative pathways in Venzuela, Ecuador, and Bolivia. Food Sovereignty: A Critical Dialogue. International Conference, New Haven, p. 1-37.

NADERIFAR, M. ; GOLI, H.; GHALJAEI, F. 2017. Snowball sampling : a purposeful method of sampling in qualitative research snowball. Strides Dev Med Educ., Kerman, v.14, n.3, pp16. https://doi.org/10.5812/sdme.67670

NEHRING, R. 2012. Politics and policies of food sovereignty in ecuador: new directions or broken promises? Policy Research Brief. Available at: $<w w w . i p c-u n d p . o r g>$. Accessed on: Feb. 11, 2019. 
OLIVEIRA, L. G.; OTÁVIO, M. B.; PETTAN. K.B. 2017. Comparative assessment of the food purchase program and the national school feeding program's impact in Ubá, Minas Gerais, Brazil. Ciência Rural, Santa Maria, v.47, n.1, p. 1-6. http://dx.doi.org/10.1590/01038478 cr20160395.

PEÑA, K. 2013. Institutionalizing food sovereignty in Ecuador. Food Sovereignty: A critical dialogue. International Conference, New Haven, p. 1-25.

PIÑEIRO, M. 2005. Rural development in Latin America : trends and policies in development. EC.IDB Rural Development Dialogue, Brussels.

PINTO-CORREIA, T.; KRISTENSEN, A. 2013. Linking research to practice: the landscape as the basis for integrating social and ecological perspectives of the rural. Landscape and Urban Planning, Amsterdam, v.120, p.9-11. https://doi.org/10.1016/j.landurbplan.2013.07.005

QU, S.Q.; DUMAY, J. 2011. The qualitative research interview. Qualitative Research in $\begin{array}{llllll}\text { Accounting } \& \text { Management, } & \text { Bingley. } & \text { V.8, n.3, } & \text { p.238-264. }\end{array}$ https://doi.org/10.1108/11766091111162070

SABOURIN, E.; SAMPER, M.; SOTOMAYOR, O. 2014. Una mirada transversal a las políticas sobre la agricultura familiar en américa latina políticas públicas y agriculturas familiares en américa latina y el caribe : balance, desafíos y perspectivas. CEPAL, Santiago. Available at: $<$ http://repositorio.cepal.org/bitstream/handle/11362/37193/S1420694_es.pdf?sequence=1>. Accesed on: Nov. 15, 2018.

SALAZAR, M. K. 1990. Interviewer bias how it affects survey research. AAOHN Journal, New Jersey, v.38, n.12, p. 567-72. https://doi.org/10.1177/216507999003801203

SAUNDERS, M.; LEWIS, P.; THORNHILL, A. 2009. Research methods for business students, New York: Pearson Education, $5^{\text {th }}$ ed. 649.

SCHNEIDER, S. 2016. Family farming in latin america and the caribbean looking for new paths of rural development and food security. FAO, Rome. Avaialbe at: <http://www.fao.org/3/ai5534e.pdf >. Accessed on: Jun. 15, 2019.

SIDANER, E.; BALABAN, D.; BURLANDY, L. 2012. The Brazilian school feeding programme: an example of an integrated programme in support of food and nutrition security. Public Health Nutrition, Cambridge, v.16, n.6, p. 989-94. https://doi.org/10.1017/S1368980012005101

WFP - WORLD FOOD PROGRAMME. 2016. Fill the nutrient gap El Salvador.WFP, Rome. Available at: <https://docs.wfp.org/api/documents/WFP0000023738/download/?_ga=2.101979137.1415650332.1607003809-

194641168.1563485446>. Accessed on: Mar. 18, 2019

WFP - WORLD FOOD PROGRAMME. 2017. World food assistance 2017. Taking stock and looking ahead. WFP, Rome. Available at: $<$ https://reliefweb.int/sites/reliefweb.int/files/resources/WFP-0000019598.pdf $>$. Accessed on: Jan. 29, 2018.

WITTMAN, H.; BLESH, J. 2015. Food sovereignty and fome zero: connecting public food procurement programmes to sustainable rural development in Brazil. The Agrarian Change, New Jersey, v.17, n.1, p. 81-105. https://doi.org/10.1111/joac.12131

Received in: November 11, 2020 Accepted in: December, 2, 2020 